\title{
Reportage fra Merapi - indonesisk vulkan i udbrud
}

Af Tom Pteiffer, Volcano Tours, og redigeret af Steen Laursen, GeoloiskNyt

Geologen Tom Pfeiffer havde det held at være ved vulkanen Merapi i Indonesien, da den gik i udbrud i maj $i$ år. Her er historien om hans jagt på et godt billede.

Efter en eventyrlig og meget smuk tur til Krakatau er er vi i en forsinket flyver på vej til Merapi. Udbruddet finder sted på kraterets sydside, hvor der har samlet sig en stor prop af ny tyktflydende lava, så det område er sikkert også der, hvor vi ser udbruddet bedst. Området syd af vulkanens kegle er også mest udsat og er derfor blevet evakueret, hører vi. Om aftenen vil vi - trods evakueringen - prøve vi at finde et godt udsigtspunkt.

\section{Første glimt af udbruddet}

Om aftenen møder vi et skilt, som med store røde bogstaver siger : "Forsigtig! Merapi". Vejen snørkler sig stejlt opad og klokken 23:50 er vi der. Bjerget ligger smukt foran os, og vi kan se røgen fra dens top og en rød glød. Et meget smukt syn. Pludselig blusser den røde glød op og belyser røgen og dampen, som stiger op over vulkanens top.

Det gør indtryk, men vi er sikre på, at vi kan finde et bedre udsigtssted på den anden side af vulkanen, selv om det er mørkt. Der er utallige veje rundt om vulkanen, og der er ikke skilte eller gode kort. Klokken 1:35 er vi stadig på Merapis norvestflanke, så vi skal rundt om bjerget. Klokken 1:57 løbet bussen tør for benzin. Chaufføren havde beregnet for lidt af den dyre benzin til den udflugt, som var vores oprindelige plan.

Fra en bus på vejen får vi benzin nok til at køre videre og kort efter standser vi ved en af de små butikker på vejen. Den er selvfølgelig lukket og landsbyen virker forladt, men det lykkes os at vække en mand og få ham til at sælge os alt den benzin, han har.

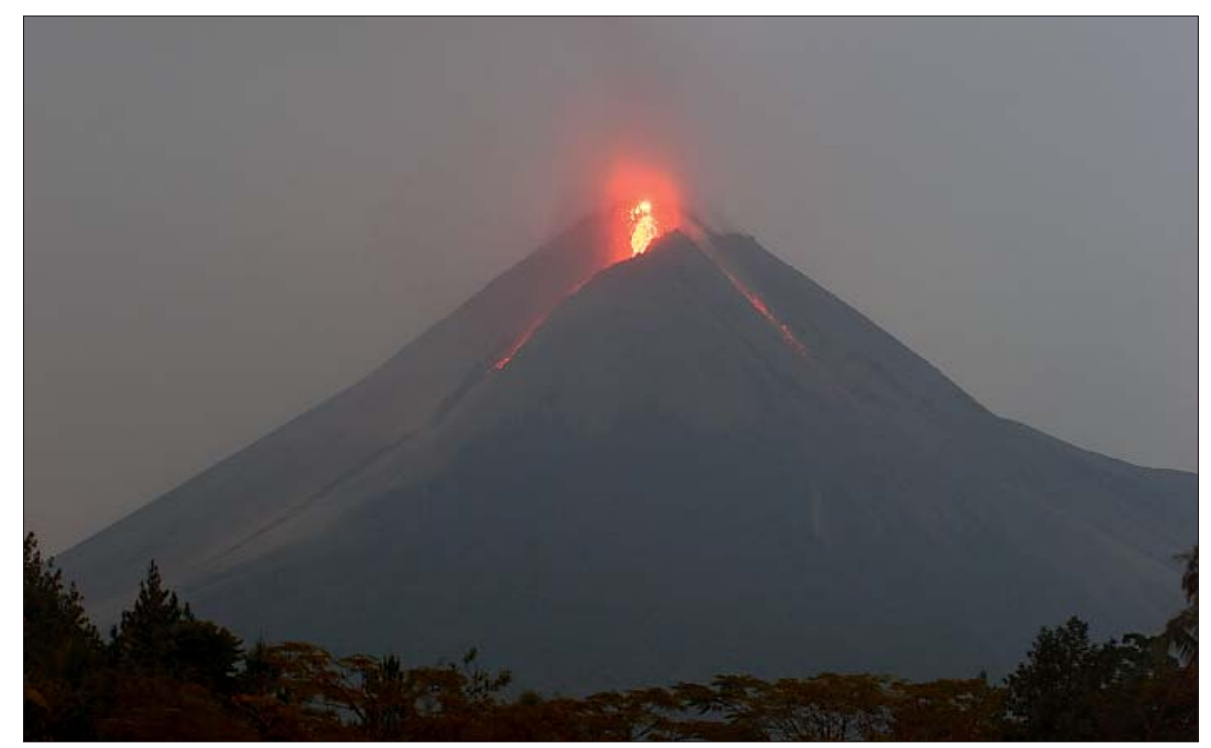

Merapi i udbrud. (Foto: Tom Pfeiffer)

På landet sælges det ikke fra tankstationer, men fra bittesmå butikker, der ofte kun består af en simpel reol ved gaden. Benzinen bliver solgt $\mathrm{i}$ brugte flasker, hvor den lysegule til klare - og nogle gange relativt mørke væske - sælges ligesom sodavand. Faktisk står benzinflaskerne i reoler som alle andre varer ved siden af vand, cigaretter, snacks og andet godt. Da vi endelig når frem, viser det sig, at vi ikke rigtigt kan se vulkanen fra udsigtspunktet....

\section{Direkte til vulkanen}

Næste nat kører vi så direkte imod området, hvor militærpolitiet bevogter de forladte landsbyer. Da vejen for alvor stiger, drejer vi til højre ad en mindre vej, kører et par kilometer og standser ved en moské. Der er kun enkelte gadelys her og der. Vi venter ti minutter, så dukker to mørke skikkelser op og stiger ind i vores minibus. Det er to lokale indbyggere, som fører os herfra.

Klokken 3:30 er vi fremme ved en lille plads. Vi kravler de få par meter op til den og kigger os omkring. Vulkanen er der. Dens glødende top står lige foran os. Den er nær, rigtigt nær. Vi er begejstrede og al træthed er glemt.

Vi ser små masser af lava løsne sig fra vulkanens glødende spids og styrte ned ad flankerne. lavaen danner to strømme, en til venstre for os, som er delvist skjult i en lille rende i flanken, og en til højre, som er utroligt smuk at se på. Det ser ud, som om ild løber ned ad vulkanen. Vi kan også skimte enkelte meget store blokke, der tumler nedad og forsvinder bag træerne. Efter et par sekunder hører vi de nedstyrtende blokkes buldren som et fjernt truende tog, der kommer imod os.

\section{De evakuerede landsbyer vågner}

Klokken er 4:00. Som et vækkeur begynder en skinger højtaler at udspy noget komplet uforståeligt gennem den stille nat. Det er en moské i nærheden, der kalder til morgenbøn. Var området ikke evakueret? Kort efter høres højtalere fra andre moskeer fra nær og fjern. Da det bliver lyst, virker området ganske normalt. Indbyggerne vender hjem tidligt om morgenen for at fodre deres. Måske er vulkanen kun farlig om natten? 